\title{
The Unfolded Protein Response: An Overview
}

\author{
Adam Read ${ }^{1,2}$ and Martin Schröder 1,2,*iD \\ 1 Department of Biosciences, Durham University, South Road, Durham DH1 3LE, UK; \\ adam.read2@durham.ac.uk \\ 2 Biophysical Sciences Institute, Durham University, South Road, Durham DH1 3LE, UK \\ * Correspondence: martin.schroeder@durham.ac.uk; Tel.: +44-191-334-1316
}

check for

updates

Citation: Read, A.; Schröder, M. The Unfolded Protein Response: An Overview. Biology 2021, 10, 384. https://doi.org/10.3390/ biology10050384

Academic Editor: Ansgar Poetsch

Received: 30 March 2021

Accepted: 27 April 2021

Published: 29 April 2021

Publisher's Note: MDPI stays neutral with regard to jurisdictional claims in published maps and institutional affiliations.

Copyright: (c) 2021 by the authors. Licensee MDPI, Basel, Switzerland. This article is an open access article distributed under the terms and conditions of the Creative Commons Attribution (CC BY) license (https:// creativecommons.org/licenses/by/ $4.0 /)$.
Simple Summary: The unfolded protein response (UPR) is the cells' way of maintaining the balance of protein folding in the endoplasmic reticulum, which is the section of the cell designated for folding proteins with specific destinations such as other organelles or to be secreted by the cell. The UPR is activated when unfolded proteins accumulate in the endoplasmic reticulum. This accumulation puts a greater load on the molecules in charge of folding the proteins, and therefore the UPR works to balance this by lowering the number of unfolded proteins present in the cell. This is done in multiple ways, such as lowering the number of proteins that need to be folded; increasing the folding ability of the endoplasmic reticulum and by removing some of the unfolded proteins which take longer to fold. If the UPR is successful at reducing the number of unfolded proteins, the UPR is inactivated and the cells protein folding balance is returned to normal. However, if the UPR is unsuccessful, then this can lead to cell death.

Abstract: The unfolded protein response is the mechanism by which cells control endoplasmic reticulum (ER) protein homeostasis. Under normal conditions, the UPR is not activated; however, under certain stresses, such as hypoxia or altered glycosylation, the UPR can be activated due to an accumulation of unfolded proteins. The activation of the UPR involves three signaling pathways, IRE1, PERK and ATF6, which all play vital roles in returning protein homeostasis to levels seen in non-stressed cells. IRE1 is the best studied of the three pathways, as it is the only pathway present in Saccharomyces cerevisiae. This pathway involves spliceosome independent splicing of HAC1 or XBP1 in yeast and mammalians cells, respectively. PERK limits protein synthesis, therefore reducing the number of new proteins requiring folding. ATF6 is translocated and proteolytically cleaved, releasing a $\mathrm{NH}_{2}$ domain fragment which is transported to the nucleus and which affects gene expression. If the UPR is unsuccessful at reducing the load of unfolded proteins in the ER and the UPR signals remain activated, this can lead to programmed cell death.

Keywords: UPR; IRE1; PERK; ATF6; RIDD; ERAD; inactivation

\section{Introduction}

The endoplasmic reticulum (ER) is a membrane-bound organelle that is responsible for folding, modification and synthesis of secretory and organelle-bound proteins. The process of protein synthesis and folding is highly controlled and is sensitive to perturbation of ER homeostasis. This situation is often referred to as ER stress. A multitude of homeostatic changes can lead to a build-up of unfolded proteins. The changes in ER homeostasis can be caused by $\mathrm{Ca}^{2+}$ depletion, hypoxia, altered glycosylation or viral infection [1-3]. Consequently, because of the accumulation of unfolded proteins, the cell has evolved a response mechanism to prevent further accumulation of unfolded proteins. This signalling pathway is known as the unfolded protein response (UPR). The UPR detects the build-up of unfolded or misfolded proteins and adjust the protein folding ability of the ER.

The UPR in mammalian cells is complex and works via three principal ER transmembrane receptors: type I transmembrane protein inositol requiring 1 (IRE1 $\alpha$ ); eukaryotic ini- 
tiation factor $2 \alpha(\mathrm{eIF} 2 \alpha)$ kinase (PERK) and activating transcription factor 6 (ATF6) [1,4-6]. The UPR attempts to process the accumulation of unfolded proteins by downregulating transcription of secretory proteins and increases the removal of misfolded or slowly folding proteins through ER-associated degradation (ERAD) or lysosomal degradation [7]. Additionally, the synthesis of ER resident chaperones and foldases is increased to promote the folding ability of the ER and to alleviate the unfolded protein burden $[8,9]$. If adaptation by the cell via the UPR is not sufficient to deal with the increased load of unfolded proteins, activation of JNK protein kinase and caspases 3, 7 and 12 occurs, which ultimately leads to an apoptotic response $[6,10]$.

IRE $1 \alpha$ is a type I transmembrane protein with a protein serine/threonine kinase and endoribonuclease domain. Activation of IRE1 $\alpha$ occurs when the ER chaperone BiP is released from its luminal domain when a build-up of unfolded proteins arises $[1,5,11]$. Once IRE $1 \alpha$ is activated, its endoribonuclease domain initiates splicing, independent of the spliceosome, of the mRNA encoding the bZIP transcription factor XBP-1 in mammals and Hac1 in yeast by its ortologue Ire1 [6,12]. PERK is also a type I transmembrane protein which shares luminal domain homology with IRE1 $\alpha$ [13]. When PERK is activated, it phosphorylates the eukaryotic translation initiation factor $2 \alpha$ (eIF2 $\alpha)$ at serine 51 [14]. Protein synthesis is inhibited by serine 51 phosphorylated eIF $2 \alpha$, which in turn reduces the number of proteins that need to be folded. ATF6 is a type II transmembrane protein. When unfolded proteins accumulate, ATF6 is transported to the Golgi complex where it is proteolytically cleaved by S1P and S2P to release the $\mathrm{NH}_{2}$ terminal-domain $[15,16]$. The cleaved section of ATF6 translocates to the nucleus, where it activates gene transcription of target genes such as GRP78, GRP94 and calnexin [17]. The ER-resident proteins that are regulated by the UPR share a common activating sequence termed the unfolded protein response element (UPRE) or ER stress response elements (ERSEs). These elements are necessary for activation of transcription in response to accumulation of unfolded proteins $[18,19]$.

\section{Ire1 in Yeast}

The UPR in yeast differs from mammals, as it lacks both ATF6 and PERK, which leaves only one known pathway originating at the IRE1 $\alpha$ orthologue Ire1 available to yeast cells to respond to accumulation of unfolded proteins in the ER. There are two proposed models for the activation of the UPR via Ire1. One model suggests direct binding of unfolded proteins to Ire1, which causes oligomerisation of Ire1. This is suggested by studies of the core of Ire1's luminal domain, which contains two interfaces [20]. Interface 1 creates a deep groove. Interface 2 allows oligomerisation. Mutating either of the interfaces decreases splicing of the HAC1 mRNA by Ire1 and decreases oligomerisation of Ire1 [21]. The grooves formed by Ire1 are similar to that of the major histocompatibility complex (MHC), which are able to bind peptides with high specificity. The Ire1 groove is lined with hydrophobic and hydrophilic residues [20]. It is also thought that due to the depth of the groove, correctly folded proteins are unable to access the groove and therefore only allow Ire1 to bind to unfolded proteins. This steric discrimination may be the reason for the specificity of Ire1 for unfolded proteins [20]. The other proposed model involves the resident ER chaperone Kar2, called BiP in mammalian cells, which is bound to inactivate Ire1 and preferentially binds to unfolded proteins when they accumulate. This releases Kar2 from Ire1 allowing it to oligomerise, which promotes trans-autophosphorylation of Ire 1 in its activation segment at serines 837, 840, 841, 850, and threonine 844 [22-24] and induction of endoribonuclease activity [1]. The target of Ire1 endoribonuclease activity is a mRNA that encodes the transcription factor Hac1 which binds to the UPRE in the promoters of target genes such as KAR2 [25,26]. During activation of the UPR, an intron of 252-nucleotides is removed from the $H A C 1$ mRNA creating the spliced form of $H A C 1$, termed $H A C 1^{i}$ (Figure 1) [19]. The next step after cleavage of $H A C 1$ mRNA by Ire1 is the ligation of the two exons by tRNA ligase. The splicing of $H A C 1$ is unique, as most other pre-mRNAs require the spliceosome and its related constituents. By contrast, the type of 
splicing for $H A C 1$ is more like pre-tRNA splicing, as it only requires two components for cleavage and ligation [27]. The newly ligated $\mathrm{mRNA}$ is then translated to an active protein able to bind to the promoter regions of target genes (Figure 1).

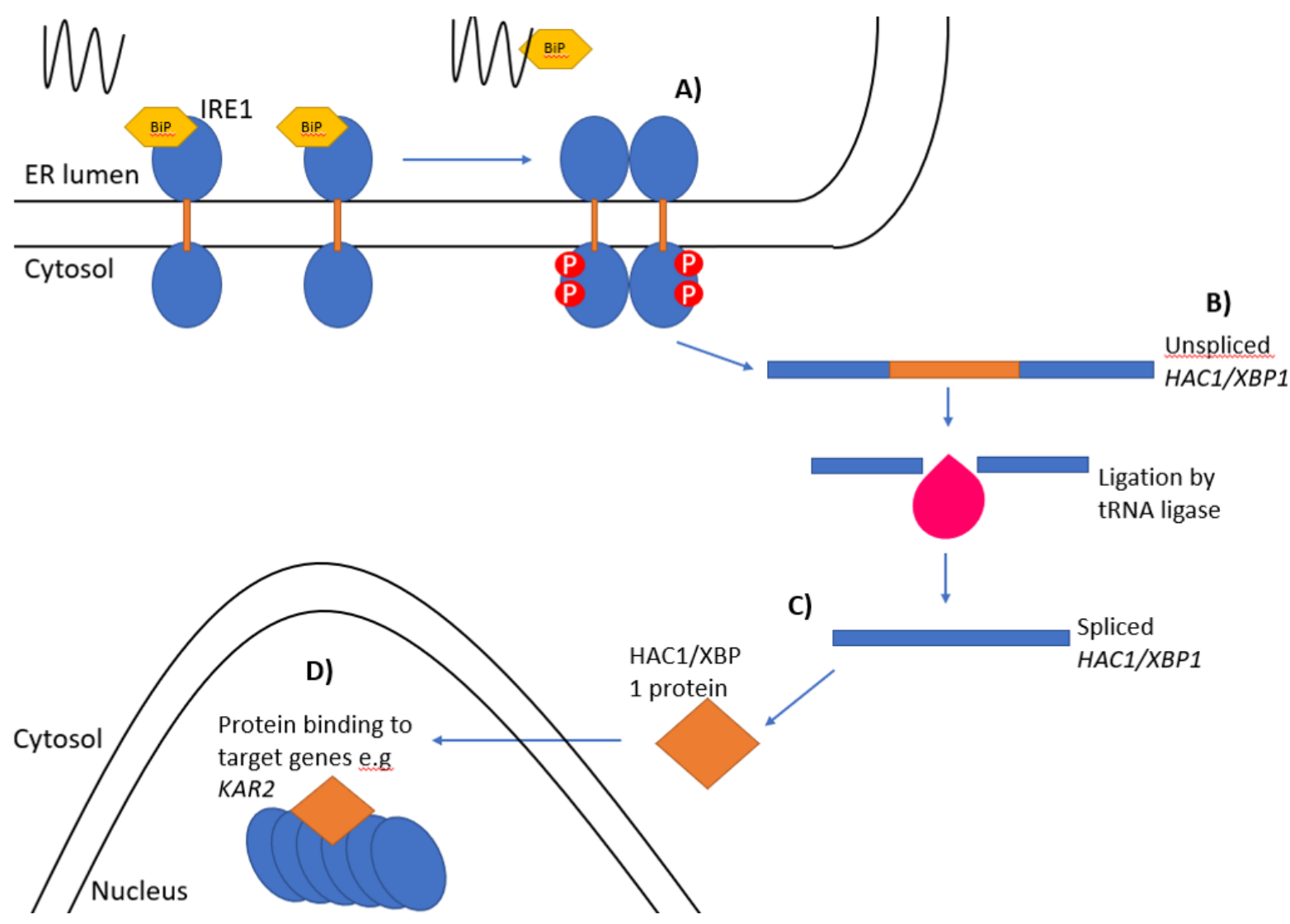

Figure 1. The unfolded protein response. The Ire1 pathway of the unfolded protein response: (A) Ire1-bound BiP/Kar2 (yellow) is released from the luminal domain of Ire1 when unfolded proteins accumulate leading to the oligomerisation and trans-autophosphorylation of Ire1 monomers. (B) Unspliced HAC1/XBP1 mRNA is spliced by the endoribonuclease domain of Ire1 and the two exons ligated together by tRNA ligase (pink). (C) The $H A C 1^{i} / X B P 1^{s}$ mRNA is then translated into an active protein. (D) The newly synthesised protein then enters the nucleus and binds to the promoter regions of target genes.

The UPR varies even among different yeast species where the Ire1 pathway is the only conserved pathway. The main difference is that some species focus on processing of HAC1 mRNA, such as Saccharomyces cerevisiae and Candida albicans [28], whereas some species, such as Schizosaccharomyces pombe, focus on the degradation of mRNAs which have been localised to the ER through a mechanism known as RIDD [28].

\section{IRE1 and RIDD}

The RNase activity of metazoan IRE1 is also involved in a different mechanism known as regulated IRE1-dependent decay (RIDD). RIDD was reported to degrade mRNAs that are localised to the ER [29]. The cleavage site for the mRNAs seems to be similar to the cleavage sequence of $X B P 1$, and the mRNA fragments are then degraded by cellular exoribonucleases [30]. IRE1 has two different isoforms, IRE1 $\alpha$ and IRE1 $\beta$, both of which have the ability to splice XBP1 and to activate RIDD, although IRE $\alpha$ shows stronger splicing activity and IRE1 $\beta$ exerts stronger RIDD activation [31]. RIDD has not been observed in S. cerevisiae, as it appears that $H A C 1$ splicing is the only target for RNase activity, whereas in S. pombe the splicing of $H A C 1$ does not occur and RIDD is the main mechanism for ER protein homeostasis [32]. It has also been demonstrated that basal levels of RIDD are required to maintain ER homeostasis. As $\mathrm{XBP1/HAC1}$ is only spliced under elevated ER 
stress, basal activity of RIDD is observed as the cleavage of mRNAs when cells are only under basal levels of ER stress. IRE1 $\beta$ has many target substrates even when ER stress is not induced, further supporting the theory of basal RIDD activity [33]. ire $1 \alpha$ and $x b p 1$ mutants were also used to investigate which one had the greater effect on ER homeostasis when not under stress and the ire $1 \alpha$ mutant altered homeostasis to a greater extent $[30,33]$. This suggests that IRE1 $\alpha$ has a way of balancing ER homeostasis even when the cell is not under stress through mechanisms such as RIDD. Under normal unstressed cells, $X B P 1 / H A C 1$ is not spliced. Once ER stress due to the accumulation of unfolded proteins occurs, $\mathrm{XBP} 1 / \mathrm{HAC1}$ splicing is present and increases until it reaches a maximum peak and then starts to decrease. RIDD is active under basal conditions and once ER stress is induced also increases. If both splicing and RIDD are able to alleviate the unfolded protein load in the ER, then homeostasis returns to normal levels [34,35]. However, if the mechanisms of XBP1/HAC1 splicing and RIDD are insufficient to normalise ER homeostasis, then, unlike splicing, which decreases over prolonged ER stress, RIDD continues increasing and degrades pre-miRNAs as well as pro-survival protein encoding mRNAs [36,37]. This ultimately leading to apoptosis of the cell and is termed prodeath RIDD [30].

\section{IRE1 Activates JNK Signaling}

Activated IRE1 $\alpha$ has also been revealed to recruit TNF receptor-associated factor 2 (TRAF2), the newly recruited TRAF2 then also recruits apoptosis signal-regulating kinase (ASK1) which directly interacts with TRAF2 [38]. Once ASK1 is recruited and activated, a signal is relayed to c-Jun amino-terminal kinase (JNK) and p38 [10]. This apoptotic pathway of IRE1 $\alpha$ further demonstrates its ability to control the fate of the cell under ER stress.

\section{Ire1 Inactivation}

The mechanism for the inactivation of Ire1, the most studied of all the UPR pathways, has yet to be fully elucidated. However, two phosphatases Dcr2 and Ptc2 have been suggested to negatively regulate yeast Ire1 [39-43]. Reversible protein phosphorylation is an important mechanism of control of protein activity which works through the antagonistic actions of protein kinases and phosphatases. Ptc2 is a protein serine/threonine phosphatase which dephosphorylates Ire1 through a direct interaction with Ire1 [39]. Ptc2 binds to Ire1 in vitro and has specificity for phosphorylated Ire1. Binding to Ire1 is independent of divalent metal ions or mutations in the metal ion binding site of Ptc2. Ptc2 dephosphorylates Ire1 in a $\mathrm{Mg}^{2+}$ or $\mathrm{Mn}^{2+}$ dependent manner [39]. The dephosphorylation inactivates Ire1 and prevents splicing of $H A C 1$, which attenuates the UPR. Cells lacking PTC2 have shown similar phenotypes to cells overexpressing Ire 1 which showed a three-fold increase in HAC1 splicing. Additionally, when catalytically inactive Ptc 2 is expressed, a similar increase in HAC1 splicing was observed which was not seen with active Ptc2 overexpression [40,42]. However, PTC2 is not necessary for cell survival during ER stress, as PTC2 null mutants still showed the same growth as wild-type cells, even though they had an increase in UPR activity $[22,39]$. This may suggest that additional phosphatases compensate for the loss of PTC2. PTC2 is also constitutively expressed and is not regulated by Ire1 or induced upon activation of the UPR. Therefore, the exact mechanism of regulation of Ire1 by Ptc2 remains unclear [39].

Dose-dependent cell cycle regulator (Dcr2) has also been suggested to negatively regulate the UPR at a step preceding HAC1 splicing [42]. Mutants with Ire1-S840ES841E or Ire1-S840A-S841A as their sole version of Ire1 represent phosphorylated and non-phosphorylated versions of Ire1, respectively [42]. Dcr2 directly interacted with the phosphomimic Ire1 mutant but not the non-phosphorylatable mutant suggesting that Dcr2 shows specificity towards phosphorylated Ire1 [42]. However, loss of DCR2 has no impact on cell survival of ER stress suggesting that Dcr2 is not the main mechanism for Ire1 dephosphorylation [22,42]. In addition, survival of ER stress was not affected by loss of both Dcr2 and Ptc2 [22], suggesting that other phosphatases are involved in inactivating Ire1, that other phosphatases can compensate for the loss of both Dcr2 and Ptc2, or that dephos- 
phorylation is not necessary for inactivation of Ire1. The kinetics of inactivation of an Ire1 mutant lacking all phosphorylation sites in its activation segment was indistinguishable from wild type Ire1 [22]. These data provide evidence for dephosphorylation-independent inactivation of Ire1 or biphasic inactivation of Ire1, where fast dephosphorylation steps precede slower dephosphorylation-independent inactivation steps.

\section{PERK Activation and Signalling}

The luminal domains of IRE1 and PERK show a small amount of homology in their luminal domains and both IRE1 and PERK from Caenorhabditis elegans can function as replacements for the luminal domain in S. cerevisiae, even though yeast does not have the PERK gene $[13,44]$. The activation of PERK is also thought to be similar to that of IRE1, as both rely on BiP bound to their luminal domains being released due to its affinity for unfolded proteins, which is followed by oligomerisation and trans-phosphorylation of PERK monomers [44], although the way in which BiP represses the activation of IRE1 and PERK may differ slightly. The BiP binding sequence in IRE1 overlaps with the region believed to be involved in oligomerisation and signalling [45], whereas in PERK, the $\mathrm{BiP}$ binding region does not overlap with the oligomerisation sequence and, therefore, is thought to interfere with PERK activation sterically [13,45]. Once activated PERK phosphorylates eukaryotic initiation factor 2 on its $\alpha$ subunit (eIF2 $\alpha$ ), Figure 2 [13]. eIF2 $\alpha$ binds to methionylated initiator methionyl-tRNA, GTP and the $40 \mathrm{~S}$ ribosomal subunit to form the $43 \mathrm{~S}$ preinitiation complex [44]. This preinitiation complex binds to the $5^{\prime}$ cap structure of mRNAs and in a $5^{\prime}$ to $3^{\prime}$ manner scans the mRNA until it reaches the first AUG codon, which then allows binding of the $60 \mathrm{~S}$ subunit to initiate translation [44]. When the two ribosomal subunits combine, the GTP in the preinitiation complex is hydrolysed to GDP. Phosphorylated eIF2 reduces the exchange of eIF2-GDP to eIF2-GTP which in turn reduces translation of upstream open reading frames (ORFs) which would normally be translated when GTP is readily available [46]. High levels of phosphorylated eIF2 $\alpha$ lead to downstream ORFs which would not be translated in normal circumstances due to the ribosomes still being bound to the mRNAs but scanning further along the mRNAs before re-initiation of translation is started due to lower amounts of GTP $[44,46,47]$. This mechanism represses translation of most mRNAs except for GCN4 in yeast and ATF4 in vertebrates, which are actually increased (Figure 2) [47,48]. ATF4 has been demonstrated to induce expression of both ATF3 and CHOP under ER stress (Figure 2). CHOP is a vital intermediary of ER stress-induced apoptosis as it induces multiple pro-apoptotic molecules such as death receptor 5 (DR5) and tribbles homologue 3 (TRB3) [49]. ATF3 is also an important molecule induced by ATF4, as ATF3 and ATF4 have been suggested to bind to the promoter region of GADD34. GADD34 is a regulatory subunit of protein phosphatase 1 , which targets protein phosphatase 1 to phosphorylated eIF $2 \alpha$, and in this way promotes dephosphorylation of eIF2 $\alpha$ (Figure 2) [49-53]. 


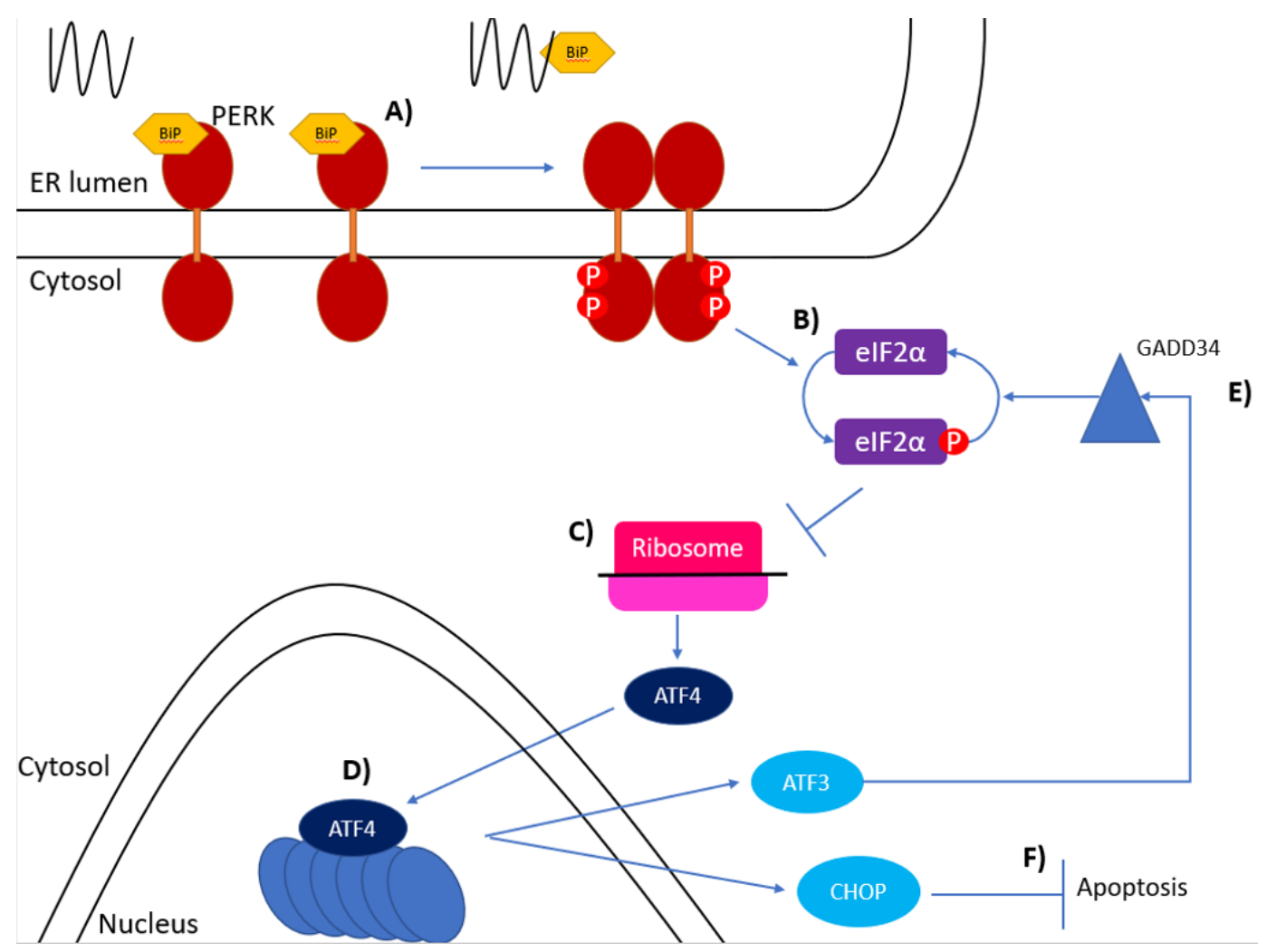

Figure 2. The PERK pathway of the unfolded protein response. (A) BiP bound to the luminal domain of PERK dissociates when unfolded proteins accumulate allowing oligomerisation and phosphorylation of the PERK monomers. (B) Phosphorylated PERK then phosphorylates eIF2 on its $\alpha$ subunit at S51. (C) Phosphorylated eIF2 $\alpha$ interferes with ribosomal translation of mRNA and causes downstream ORFs to be translated, such as ATF4. (D) ATF4 induces expression of ATF3 and CHOP.

(E) ATF3 binds to the promoter region of GADD34 which activates a protein phosphatase which dephosphorylates eIF2 $\alpha$.

(F) CHOP induces ER stress-induced apoptosis.

\section{ATF6 Signalling}

ATF6 is a type II transmembrane protein and the third pathway which plays a vital role in UPR signalling. Similarly to IRE1 and PERK, this transmembrane protein is also bound to $\mathrm{BiP}$ in its inactive state and requires dissociation of BiP before the signalling cascade can activate [44]. Regulated intermembrane proteolysis (RIP) is the process by which transmembrane proteins such as ATF6 are cleaved to release their cytoplasmic domains which then regulate gene expression by entering the nucleus $[15,52]$. The mechanism for the activation of ATF6 is best represented by the model for sterol regulatory element binding proteins (SREBPs), which are transcription factors important in the synthesis of cholesterol [53]. The SREBPs are also embedded in the ER membrane with their $\mathrm{NH}_{2}-$ terminal and $\mathrm{COOH}$-terminal segments projecting into the cytosol and a hydrophilic loop facing the ER lumen which is similar to ATF6 as its $\mathrm{NH}_{2}$ domain also projects into the cytosol [15]. The next step for SREBPs is to bind with SREBP cleavage activating-protein (SCAP), which transports the SREBPs to the Golgi complex, where RIP occurs [54,55]. Site-1 protease (S1P) is a membrane-anchored serine protease that cleaves the recognition sequence RXXL, where $X$ can be any amino acid $[15,56]$. S1P cleavage splits the two transmembrane domains, with the $\mathrm{NH}_{2}$-terminal segment being termed as the intermediary fragment (Figure 3) [15]. Site-2 protease (S2P) is responsible for cleaving the intermediary fragment, which releases the $\mathrm{NH}_{2}$-terminal fragment that then localises to the nucleus and binds to promotor regions initiating gene expression (Figure 3) [57,58]. The same RXXL sequence has been detected in the luminal domain of ATF6 which suggests that S1P may also cleave ATF6 in a similar manner to SREBP-2 [15,17]. However, an equivalent molecule 
to SCAP has not been identified for ATF6. Therefore, the transport of ATF6 to where S1P is localised, which is usually in or near the Golgi complex, remains unknown [15].

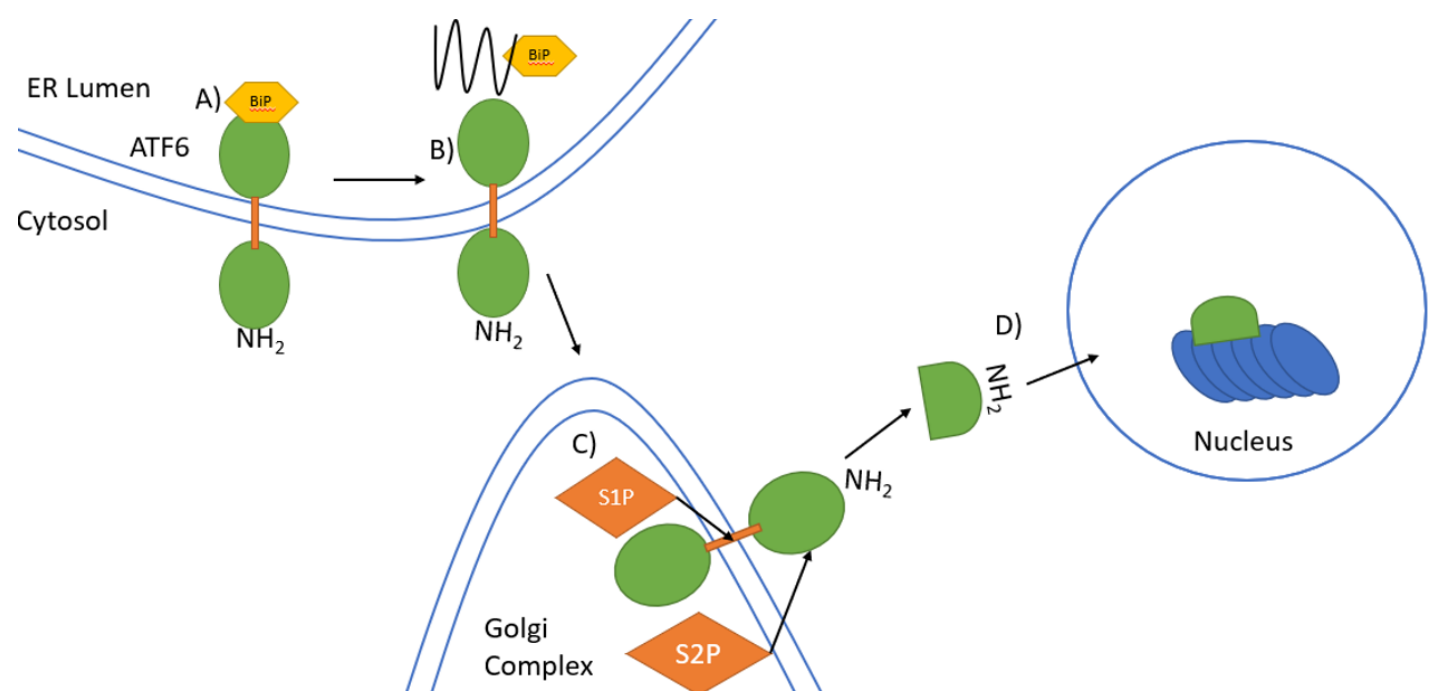

Figure 3. Signal transduction by ATF6 in the UPR. (A) In unstressed conditions, binding of BiP to the COOH terminal ER luminal domain of the type II transmembrane protein ATF6 keeps ATF6 inactive. The $\mathrm{NH}_{2}$ terminal domain is located in the cytosol. (B) Under ER stress unfolded proteins accumulate leading to dissociation of BiP from ATF6. ATF6 then translocates to the Golgi complex from the ER. (C) ATF6 is first cleaved by S1P in the transmembrane domains and then by S2P in the cytosolic domain near the ER membrane to release the $\mathrm{NH}_{2}$-terminal domain. (D) The $\mathrm{NH}_{2}$-terminal domain migrates to the nucleus where it induces gene expression.

\section{ERAD Induction}

ER-associated degradation (ERAD) is a mechanism by which slowly folding or misfolded proteins are cleared from the ER and degraded [8]. The clearance and degradation of these unfolded or misfolded protein helps to alleviate the accumulation of unfolded proteins during ER stress. The UPR and ERAD are known to functionally connect to each other. Cells with compromised ERAD display constant UPR activation due to misfolded proteins not being degraded $[43,59,60]$. In mammalian cells, ATF4 and ATF6 have been suggested to induce HERP/Mif1, an ER membrane protein which is known to interact with the $26 \mathrm{~S}$ proteosome, which brings proteosomes closer to the ER allowing for efficient ERAD [43]. Additionally, herp ${ }^{-/-}$cells have shown greater susceptibility to ER stress and demonstrated increased UPR signaling as well as stabilisation of an endogenous ERAD substrate [61]. Multiple genes involved in ERAD, such as EDEM, HRD1 and UGGT, require induction by XBP1. EDEM recognises and targets unfolded proteins for degradation [62]. It has also been suggested that the UPR may work in two phases. Phase one allows the unfolded proteins time to refold without being degraded and phase two degrades any proteins which have failed to fold [63]. This is believed to occur due to ATF6 activating quickly when compared to IRE1, which has to induce XBP1 splicing and translation of $X B P 1$ to an active protein. During this time, the ER chaperones induced by ATF6 are able to promote protein folding before spliced XBP1 induces ERAD genes which promote the degradation of unfolded proteins $[63,64]$.

\section{Future Perspectives}

The importance of protein folding homeostasis in the ER has been demonstrated to have a vital role in the function and growth, as well as being a major regulator at transcriptional, translational and post-translational levels. The basic mechanisms of action have been established for IRE1, PERK and ATF6. However, a deeper understanding of the interactions of these signaling pathways with molecular chaperones is needed. There are still important questions left unanswered. Are all UPR pathways regulated in the 
same manner? Is BiP the only molecular chaperone involved at the start of all three UPR pathways, or has the importance of BiP been overstated and do other molecular chaperones contribute to the regulation of the ER stress sensors? The factors that regulate the UPR pathways still remain uncertain. The characterisation of these factors could lead to a greater understanding of the effect that the UPR has in the cell. For example, the UPR is not only focused on clearing accumulated unfolded proteins, but it also has the ability to initiate or prevent apoptosis. Therefore, understanding all the factors involved in the UPR could demonstrate the ability of the UPR to affect previously unrelated pathways.

Author Contributions: For research articles with several authors, the following statements should be used "Conceptualization, A.R. and M.S.; writing-original draft preparation, A.R.; writingreview and editing, A.R. and M.S. All authors have read and agreed to the published version of the manuscript."

Funding: This research received no external funding.

Institutional Review Board Statement: Not applicable.

Informed Consent Statement: Not applicable.

Data Availability Statement: Not applicable.

Conflicts of Interest: The authors declare no conflict of interest.

\section{References}

1. Stewart Siyan, C.; Randal, J.K. Unfolded protein response. Curr. Biol. 2012, 22, R622-R626. [CrossRef]

2. Ron, D. Translational control in the endoplasmic reticulum stress response. J. Clin. Investig. 2002, 110, 1383-1388. [CrossRef]

3. Chakrabarti, A.; Chen, A.W.; Varner, J.D. A review of the mammalian unfolded protein response. Biotechnol Bioeng 2011, 108, 2777-2793. [CrossRef]

4. Kaufman, R.J.; Scheuner, D.; Schröder, M.; Shen, X.; Lee, K.; Liu, C.Y.; Arnold, S.M. The unfolded protein response in nutrient sensing and differentiation. Nat. Rev. Mol. Cell Biol. 2002, 3, 411-421. [CrossRef]

5. Schröder, M.; Clark, R.; Kaufman, R.J. IRE1- and HAC1-independent transcriptional regulation in the unfolded protein response of yeast. Mol. Microbiol. 2003, 49, 591-606. [CrossRef]

6. Shen, X.; Ellis, R.E.; Lee, K.; Liu, C.-Y.; Yang, K.; Solomon, A.; Yoshida, H.; Morimoto, R.; Kurnit, D.M.; Mori, K.; et al. Complementary Signaling Pathways Regulate the Unfolded Protein Response and Are Required for C. elegans Development. Cell 2001, 107, 893-903. [CrossRef]

7. Sidrauski, C.; Walter, P. The Transmembrane Kinase Ire1p Is a Site-Specific Endonuclease That Initiates mRNA Splicing in the Unfolded Protein Response. Cell 1997, 90, 1031-1039. [CrossRef]

8. Travers, K.J.; Patil, C.K.; Wodicka, L.; Lockhart, D.J.; Weissman, J.S.; Walter, P. Functional and Genomic Analyses Reveal an Essential Coordination between the Unfolded Protein Response and ER-Associated Degradation. Cell 2000, 101, 249-258. [CrossRef]

9. Kozutsumi, Y.; Segal, M.; Normington, K.; Gething, M.-J.; Sambrook, J. The presence of malfolded proteins in the endoplasmic reticulum signals the induction of glucose-regulated proteins. Nature 1988, 332, 462-464. [CrossRef]

10. Urano, F.; Wang, X.; Bertolotti, A.; Zhang, Y.; Chung, P.; Harding, H.P.; Ron, D. Coupling of stress in the ER to activation of JNK protein kinases by transmembrane protein kinase IRE1. Science 2000, 287, 664-666. [CrossRef]

11. Bertolotti, A.; Zhang, Y.H.; Hendershot, L.M.; Harding, H.P.; Ron, D. Dynamic interaction of BiP and ER stress transducers in the unfolded-protein response. Nat. Cell Biol. 2000, 2, 326-332. [CrossRef]

12. Bashir, S.; Banday, M.; Qadri, O.; Bashir, A.; Hilal, N.; Nida i, F.; Rader, S.; Fazili, K.M. The molecular mechanism and functional diversity of UPR signaling sensor IRE1. Life Sci. 2021, 265, 118740. [CrossRef]

13. Liu, C.Y.; Schröder, M.; Kaufman, R.J. Ligand-independent Dimerization Activates the Stress Response Kinases IRE1 and PERK in the Lumen of the Endoplasmic Reticulum*. J. Biol. Chem. 2000, 275, 24881-24885. [CrossRef]

14. Scheuner, D.; Song, B.; McEwen, E.; Liu, C.; Laybutt, R.; Gillespie, P.; Saunders, T.; Bonner-Weir, S.; Kaufman, R.J. Translational Control Is Required for the Unfolded Protein Response and In Vivo Glucose Homeostasis. Mol. Cell 2001, 7, 1165-1176. [CrossRef]

15. Ye, J.; Rawson, R.B.; Komuro, R.; Chen, X.; Davé, U.P.; Prywes, R.; Brown, M.S.; Goldstein, J.L. ER Stress Induces Cleavage of Membrane-Bound ATF6 by the Same Proteases that Process SREBPs. Mol. Cell 2000, 6, 1355-1364. [CrossRef]

16. Haze, K.; Yoshida, H.; Yanagi, H.; Yura, T.; Mori, K. Mammalian Transcription Factor ATF6 Is Synthesized as a Transmembrane Protein and Activated by Proteolysis in Response to Endoplasmic Reticulum Stress. Mol. Biol. Cell 1999, 10, 3787-3799. [CrossRef]

17. Wang, Y.; Shen, J.; Arenzana, N.; Tirasophon, W.; Kaufman, R.J.; Prywes, R. Activation of ATF6 and an ATF6 DNA Binding Site by the Endoplasmic Reticulum Stress Response*. J. Biol. Chem. 2000, 275, 27013-27020. [CrossRef]

18. Mori, K.; Sant, A.; Kohno, K.; Normington, K.; Gething, M.; Sambrook, J. A 22 bp cis-acting element is necessary and sufficient for the induction of the yeast KAR2 (BiP) gene by unfolded proteins. Embo J. 1992, 11, 2583-2593. [CrossRef] 
19. Sidrauski, C.; Cox, J.S.; Walter, P. tRNA Ligase Is Required for Regulated mRNA Splicing in the Unfolded Protein Response. Cell 1996, 87, 405-413. [CrossRef]

20. Credle, J.J.; Finer-Moore, J.S.; Papa, F.R.; Stroud, R.M.; Walter, P. On the mechanism of sensing unfolded protein in the endoplasmic reticulum. Proc. Natl. Acad. Sci. USA 2005, 102, 18773-18784. [CrossRef] [PubMed]

21. Gardner, B.M.; Walter, P. Unfolded proteins are Ire1-activating ligands that directly induce the unfolded protein response. Sci. (New York N.Y.) 2011, 333, 1891-1894. [CrossRef]

22. Armstrong, M.C.; Šestak, S.; Ali, A.A.; Sagini, H.A.; Brown, M.; Baty, K.; Treumann, A.; Schröder, M. Bypass of activation loop phosphorylation by aspartate 836 in activation of the endoribonuclease activity of Ire1. Mol. Cell. Biol. 2017, 37. [CrossRef]

23. Shamu, C.E.; Walter, P. Oligomerization and phosphorylation of the Ire1p kinase during intracellular signaling from the endoplasmic reticulum to the nucleus. EMBO J. 1996, 15, 3028-3039. [CrossRef]

24. Lee, K.P.; Dey, M.; Neculai, D.; Cao, C.; Dever, T.E.; Sicheri, F. Structure of the dual enzyme Ire1 reveals the basis for catalysis and regulation in nonconventional RNA splicing. Cell 2008, 132, 89-100. [CrossRef]

25. Nikawa, J.-i.; Akiyoshi, M.; Hirata, S.; Fukuda, T. Saccharomyces Cerevisiae IRE2/HAC1 Is Involved in IRE1-Mediated KAR2 Expression. Nucleic Acids Res. 1996, 24, 4222-4226. [CrossRef]

26. Niwa, M.; Sidrauski, C.; Kaufman, R.J.; Walter, P. A Role for Presenilin-1 in Nuclear Accumulation of Ire1 Fragments and Induction of the Mammalian Unfolded Protein Response. Cell 1999, 99, 691-702. [CrossRef]

27. Gonzalez, T.N.; Sidrauski, C.; Dörfler, S.; Walter, P. Mechanism of non-spliceosomal mRNA splicing in the unfolded protein response pathway. EMBO J. 1999, 18, 3119-3132. [CrossRef]

28. Hernández-Elvira, M.; Torres-Quiroz, F.; Escamilla-Ayala, A.; Domínguez-Martin, E.; Escalante, R.; Kawasaki, L.; Ongay-Larios, L.; Coria, R. The unfolded protein response pathway in the yeast Kluyveromyces lactis. a comparative view among yeast species. Cells 2018, 7, 106. [CrossRef]

29. Hollien, J.; Lin, J.H.; Li, H.; Stevens, N.; Walter, P.; Weissman, J.S. Regulated Ire1-dependent decay of messenger RNAs in mammalian cells. J. Cell Biol. 2009, 186, 323-331. [CrossRef]

30. Maurel, M.; Chevet, E.; Tavernier, J.; Gerlo, S. Getting RIDD of RNA: IRE1 in cell fate regulation. Trends Biochem. Sci. 2014, 39, 245-254. [CrossRef] [PubMed]

31. Imagawa, Y.; Hosoda, A.; Sasaka, S.-i.; Tsuru, A.; Kohno, K. RNase domains determine the functional difference between IRE1 $\alpha$ and IRE1ß. FEBS Lett. 2008, 582, 656-660. [CrossRef] [PubMed]

32. Kimmig, P.; Diaz, M.; Zheng, J.; Williams, C.C.; Lang, A.; Aragón, T.; Li, H.; Walter, P. The unfolded protein response in fission yeast modulates stability of select mRNAs to maintain protein homeostasis. eLife 2012, 1, e00048. [CrossRef]

33. Lipson, K.L.; Fonseca, S.G.; Ishigaki, S.; Nguyen, L.X.; Foss, E.; Bortell, R.; Rossini, A.A.; Urano, F. Regulation of insulin biosynthesis in pancreatic beta cells by an endoplasmic reticulum-resident protein kinase IRE1. Cell Metab. 2006, 4, 245-254. [CrossRef]

34. Korennykh, A.; Walter, P. Structural basis of the unfolded protein response. Annu. Rev. Cell Dev. Biol. 2012, 28, 251-277. [CrossRef]

35. Gaddam, D.; Stevens, N.; Hollien, J. Comparison of mRNA localization and regulation during endoplasmic reticulum stress in Drosophila cells. Mol. Biol. Cell 2013, 24, 14-20. [CrossRef]

36. Upton, J.-P.; Wang, L.; Han, D.; Wang, E.S.; Huskey, N.E.; Lim, L.; Truitt, M.; McManus, M.T.; Ruggero, D.; Goga, A. IRE1 $\alpha$ cleaves select microRNAs during ER stress to derepress translation of proapoptotic Caspase-2. Science 2012, 338, 818-822. [CrossRef]

37. Hollien, J.; Weissman, J.S. Decay of endoplasmic reticulum-localized mRNAs during the unfolded protein response. Science 2006, 313, 104-107. [CrossRef]

38. Nishitoh, H.; Matsuzawa, A.; Tobiume, K.; Saegusa, K.; Takeda, K.; Inoue, K.; Hori, S.; Kakizuka, A.; Ichijo, H. ASK1 is essential for endoplasmic reticulum stress-induced neuronal cell death triggered by expanded polyglutamine repeats. Genes Dev. 2002, 16, 1345-1355. [CrossRef]

39. Welihinda, A.A.; Tirasophon, W.; Green, S.R.; Kaufman, R.J. Protein Serine/Threonine Phosphatase Ptc2p Negatively Regulates the Unfolded-Protein Response by Dephosphorylating Ire1p Kinase. Mol. Cell. Biol. 1998, 18, 1967-1977. [CrossRef]

40. Valkonen, M.; Penttilä, M.; Saloheimo, M. The ire1 and ptc2 genes involved in the unfolded protein response pathway in the filamentous fungus Trichoderma reesei. Mol. Genet. Genom. 2004, 272, 443-451. [CrossRef]

41. Guo, J.; Polymenis, M. Dcr2 targets Ire1 and downregulates the unfolded protein response in Saccharomyces cerevisiae. EMBO Rep. 2006, 7, 1124-1127. [CrossRef]

42. Cox, J.S.; Walter, P. A novel mechanism for regulating activity of a transcription factor that controls the unfolded protein response. Cell 1996, 87, 391-404. [CrossRef]

43. Theo van, L.; Alex, J.v.d.E.; Carrol, T. Mif1: A Missing Link between the Unfolded Protein Response Pathway and ER-Associated Protein Degradation? Curr. Protein Pept. Sci. 2001, 2, 169-190. [CrossRef]

44. Schröder, M.; Kaufman, R.J. THE MAMMALIAN UNFOLDED PROTEIN RESPONSE. Annu. Rev. Biochem. 2005, 74, 739-789. [CrossRef]

45. Liu, C.Y.; Xu, Z.; Kaufman, R.J. Structure and Intermolecular Interactions of the Luminal Dimerization Domain of Human IRE1 $\alpha^{*}$. J. Biol. Chem. 2003, 278, 17680-17687. [CrossRef]

46. Ma, K.; Vattem, K.M.; Wek, R.C. Dimerization and Release of Molecular Chaperone Inhibition Facilitate Activation of Eukaryotic Initiation Factor-2 Kinase in Response to Endoplasmic Reticulum Stress*. J. Biol. Chem. 2002, 277, 18728-18735. [CrossRef]

47. Vattem, K.M.; Wek, R.C. Reinitiation involving upstream ORFs regulates $\mathrm{ATF}_{4}$ mRNA translation in mammalian cells. Proc. Natl. Acad. Sci. USA 2004, 101, 11269-11274. [CrossRef] 
48. Harding, H.P.; Novoa, I.; Zhang, Y.; Zeng, H.; Wek, R.; Schapira, M.; Ron, D. Regulated Translation Initiation Controls StressInduced Gene Expression in Mammalian Cells. Mol. Cell 2000, 6, 1099-1108. [CrossRef]

49. Jiang, H.-Y.; Wek, S.A.; McGrath, B.C.; Lu, D.; Hai, T.; Harding, H.P.; Wang, X.; Ron, D.; Cavener, D.R.; Wek, R.C. Activating Transcription Factor 3 Is Integral to the Eukaryotic Initiation Factor 2 Kinase Stress Response. Mol. Cell. Biol. 2004, 24, 1365-1377. [CrossRef] [PubMed]

50. Novoa, I.; Zeng, H.; Harding, H.P.; Ron, D. Feedback Inhibition of the Unfolded Protein Response by GADD34-Mediated Dephosphorylation of eIF2 $\alpha$. J. Cell Biol. 2001, 153, 1011-1022. [CrossRef] [PubMed]

51. Ma, Y.; Hendershot, L.M. Delineation of a Negative Feedback Regulatory Loop That Controls Protein Translation during Endoplasmic Reticulum Stress*. J. Biol. Chem. 2003, 278, 34864-34873. [CrossRef]

52. Brown, M.S.; Ye, J.; Rawson, R.B.; Goldstein, J.L. Regulated intramembrane proteolysis: A control mechanism conserved from bacteria to humans. Cell 2000, 100, 391-398. [CrossRef]

53. Brown, M.S.; Goldstein, J.L. The SREBP pathway: Regulation of cholesterol metabolism by proteolysis of a membrane-bound transcription factor. Cell 1997, 89, 331-340. [CrossRef]

54. Nohturfft, A.; Yabe, D.; Goldstein, J.L.; Brown, M.S.; Espenshade, P.J. Regulated step in cholesterol feedback localized to budding of SCAP from ER membranes. Cell 2000, 102, 315-323. [CrossRef]

55. Sakai, J.; Nohturfft, A.; Goldstein, J.L.; Brown, M.S. Cleavage of sterol regulatory element-binding proteins (SREBPs) at site-1 requires interaction with SREBP cleavage-activating protein: Evidence from in vivo competition studies. J. Biol. Chem. 1998, 273, 5785-5793. [CrossRef] [PubMed]

56. Duncan, E.A.; Brown, M.S.; Goldstein, J.L.; Sakai, J. Cleavage site for sterol-regulated protease localized to a Leu-Ser bond in the lumenal loop of sterol regulatory element-binding protein-2. J. Biol. Chem. 1997, 272, 12778-12785. [CrossRef]

57. Zelenski, N.G.; Rawson, R.B.; Brown, M.S.; Goldstein, J.L. Membrane Topology of S2P, a Protein Required for Intramembranous Cleavage of Sterol Regulatory Element-binding Proteins*. J. Biol. Chem. 1999, 274, 21973-21980. [CrossRef]

58. Rawson, R.B.; Zelenski, N.G.; Nijhawan, D.; Ye, J.; Sakai, J.; Hasan, M.T.; Chang, T.; Brown, M.S.; Goldstein, J.L. Complementation cloning of S2P, a gene encoding a putative metalloprotease required for intramembrane cleavage of SREBPs. Mol. Cell 1997, 1, 47-57. [CrossRef]

59. Hwang, J.; Qi, L. Quality control in the endoplasmic reticulum: Crosstalk between ERAD and UPR pathways. Trends Biochem. Sci. 2018, 43, 593-605. [CrossRef]

60. Wu, S.; Stone, S.; Nave, K.-A.; Lin, W. The Integrated UPR and ERAD in Oligodendrocytes Maintain Myelin Thickness in Adults by Regulating Myelin Protein Translation. J. Neurosci. 2020, 40, 8214-8232. [CrossRef]

61. Hori, O.; Ichinoda, F.; Yamaguchi, A.; Tamatani, T.; Taniguchi, M.; Koyama, Y.; Katayama, T.; Tohyama, M.; Stern, D.M.; Ozawa, K.; et al. Role of Herp in the endoplasmic reticulum stress response. Genes Cells 2004, 9, 457-469. [CrossRef]

62. Hosokawa, N.; Tremblay, L.O.; You, Z.; Herscovics, A.; Wada, I.; Nagata, K. Enhancement of Endoplasmic Reticulum (ER) Degradation of Misfolded Null Hong Kong $\alpha 1$-Antitrypsin by Human ER Mannosidase I*. J. Biol. Chem. 2003, 278, 26287-26294. [CrossRef] [PubMed]

63. Yoshida, H.; Matsui, T.; Hosokawa, N.; Kaufman, R.J.; Nagata, K.; Mori, K. A Time-Dependent Phase Shift in the Mammalian Unfolded Protein Response. Dev. Cell 2003, 4, 265-271. [CrossRef]

64. Qu, J.; Zou, T.; Lin, Z. The Roles of the Ubiquitin-Proteasome System in the Endoplasmic Reticulum Stress Pathway. Int. J. Mol. Sci. 2021, 22, 1526. [CrossRef] [PubMed] 